Campen, C. van, Cardol, M. When work and satisfaction with life do not go hand in hand: health barriers and personal resources in the participation of people with chronic physical disabilities.)

\begin{tabular}{|l|l|}
\hline $\begin{array}{l}\text { Postprint } \\
\text { Version }\end{array}$ & 1.0 \\
\hline $\begin{array}{l}\text { Journal website } \\
\text { Pubmed link }\end{array}$ & $\underline{\text { http://dx.doi.org/10.1016/j.socscimed.2009.04.014 }}$ \\
\hline DOI & $\underline{\mathrm{http} / / / \mathrm{www} \text {.ncbi.nlm.nih.gov/pubmed/19447537 }}$ \\
\hline
\end{tabular}

This is a NIVEL certified Post Print, more info at http://www.nivel.eu

\title{
When work and satisfaction with life do not go hand in hand: Health barriers and personal resources in the participation of people with chronic physical disabilities
}

\author{
CRETIEN VAN CAMPEN ${ }^{\mathrm{A}}$ AND MIEKE CARDOL ${ }^{\mathrm{B}}$
}

${ }^{a}$ Netherlands Institute for Social Research (SCP), P.O. Box 16164, 2500 BD, The Hague, Netherlands

${ }^{\mathrm{b}}$ NIVEL (Netherlands Institute for Health Services Research), Netherlands

\begin{abstract}
People with chronic physical disabilities participate less in both paid and voluntary work and are less satisfied with their lives than people without health problems. Governments and scientists have suggested that participation in employment is the main road to well-being. We analysed national survey data on the participation in work and satisfaction with life, comparing people with a chronic illness and a physical disability $(n=603)$ to people with a chronic illness but without a physical disability $(n=1199)$ and the general population $(n=6128)$ in the Netherlands. The results show that the relationship between happiness and work is different for people with a chronic illness and a physical disability, as compared to the other two populations. Fewer people with a chronic illness and disability were categorized as 'satisfied people with work' (i.e. participating in work and satisfied with their life), while most people belonged to a group of 'satisfied people without work' and, surprisingly, not to the expected group of 'dissatisfied people without work'. In order to explain this exceptional distribution we modelled satisfied participation in work as an outcome of a balance between personal resources and barriers. By means of discriminant regression analysis, we identified the severity of motor disability as the main barrier, and education level and age, as the main resource factors that distinguish between 'satisfied people with work' and others among the group of people with a chronic illness and a physical disability.
\end{abstract}

\section{INTRODUCTION}

Participation in work is an important 'life activity', offering income, social relationships, social status, daily rhythms, and often, meaning in life. It is associated with higher levels of well-being in the general population ([Argyle, 1989], [Diener and Suh, 1997] and [Frey and 
Campen, C. van, Cardol, M. When work and satisfaction with life do not go hand in hand: health barriers and personal resources in the participation of people with chronic physical disabilities.

Social Science \& Medicine: 2009, 69(1), 56-60

Stutzer, 2002]). Health problems are found to affect this relationship ([Bent et al., 2001], [Dijkers, 1999], [Manns and Chad, 1999], [Oswald and Powdthavee, 2006] and [Post et al., 1998]). People with a chronic illness and a physical disability show lower employment figures (Office for Disability Issues, 2004), and they rate their well-being lower than people without health problems ([Oswald and Powdthavee, 2006] and [Ville and Ravaud, 2001]).

Though one would expect that both participation in work and subjective well-being vary according to the severity of health problems, participation in employment and well-being appears to be less associated when adjusted for the severity of physical disability (van Campen \& Iedema, 2007). More studies suggest that work participation and subjective wellbeing vary along different lines in populations of people with chronic physical disabilities. People with paraplegia, often wheelchairusers, attribute different values such as personal fulfilment and social recognition, to work and not working, in contrast to non-disabled persons ([Ville and Ravaud, 1998] and [Ville and Winance, 2006]). The subjective experience of disablement and the effect of opportunities differ between people born with a disability and those who acquire it later in life. Also cultural differences in perceptions and expectations play a mediating role between work and happiness. This is demonstrated in interviews with Italian and Nepalese people with disabilities with regard to their opportunities for work and mobility (delle Fave \& Massimini, 2005). For these and other reasons, people with disabilities follow different work trajectories than non-disabled persons. People with a chronic disease or disability have more trouble in finding employment that fits their interests and competencies than healthy people ([van Lindert et al., 2006] and [Tagalakis et al., 1988]).

It is not just participation in work, but meaningful and satisfying participation in work and society that should be a policy target for governments aiming to improve the well-being of people with chronic diseases and disabilities (Edwards \& Imrie, 2008). Instead of using work participation, that is the percentage of people doing paid or voluntary work, we suggest the concept of 'satisfying participation' should be used. This we define as: realizing societal roles, with or without support, in a meaningful and satisfying way (van Campen \& Cardol, 2007). This definition combines the concepts of participation and satisfaction with life.

A fundamental issue is how, and to what extent, participation in work is related to satisfaction with life for people with a chronic physical disability. In this study we evaluated first the relationship between work and life satisfaction for three populations: people with a chronic illness and a physical disability; people with a chronic illness but without physical disability; and the general population. Secondly, we analysed how many people realize a 'satisfying participation' in work in the three populations. Thirdly, we analysed what barriers and resources distinguish satisfied participants from others among people with a chronic illness and a physical disability. Note that work participation and being satisfied with life is a broader concept than 'job satisfaction' which only applies to workers.

\section{METHODS}

The data for this study were collected within the Panel of Patients with Chronic Diseases (PPCD) between 2001 and 2004. Members of the panel were recruited via general practices. This panel consisted of almost two thousand people, all diagnosed with a chronic physical disease by a medical practitioner. Before patients enrolled the panel, their informed consent was obtained. The panel is registered with the Dutch Data Protection Authority, and the data were collected according to the privacy protection guidelines of the Authority. The panel sample consisted of 1802 people with a chronic disease, including 603 people with a moderate or serious disability (Table 1). Excluded were people younger than 15 years of age, people living in an institution, and people facing the final stage of a terminal illness. The panel is a representative sample of the Dutch population of people with a chronic illness and possible motor disabilities (Heijmans, Spreeuwenberg, \& Rijken, 2005). Twice a year participants in the panel received a postal questionnaire. The items in the questionnaires 
Campen, C. van, Cardol, M. When work and satisfaction with life do not go hand in hand: healthe barriers and personal resources in the participation of people with chronic physical disabilities.

Social Science \& Medicine: 2009, 69(1), 56-60

were related to care and care needs, participation and participation needs, social situation and quality of life.

\section{[TABLE 1.]}

For data on the general population, the Dutch permanent survey of people's situation in life (POLS) - Basic Module plus the Module on Health and Work, the 2002 edition, published by Statistics Netherlands (CBS, www.cbs.nl) were used. This survey of personal interviews and additional written questionnaires provides a nationally representative dataset on people from the non-institutional population aged 12 years and over in the Netherlands. The sample of the general population consists of 6128 Dutch people aged 16 years and over (Table 1).

The OECD Long-term Disability Questionnaire (OECD, 1981) was used to evaluate the presence and severity of disabilities. The OECD includes items on motor, visual and hearing disabilities. Responses were categorized into 'no or mild disability' and 'moderate or serious disability'.

Demographic characteristics, such as age, educational level, living situation and comorbidity of the panel members were recorded at the time their membership started. The socio-economic variables net household income and highest level of education were measured in 16 and 9 categories respectively. Participation in work was measured by two questions: "Do you have paid work at this moment?" and: "Do you do voluntary work at this moment?" Respondents that confirmed one or both questions were included in the group of working respondents. Though paid and voluntary work do differ in a number of respects, we included both because we did not want to exclude the large group of persons with a physical disability who are aged over 65 . Both paid and voluntary work are important means of social participation for people with disabilities. Unfortunately, the number of respondents with physical disabilities did not allow for separate analyses of people with paid work, those with voluntary work, or both.

Subjective well-being can be operationalized in different ways (cf. [Deci and Ryan, 2008] and [Diener and Suh, 1997]), like life satisfaction (Diener, Emmons, Larsen, \& Griffin, 1985), positive affect (Lyubomirsky, King, \& Diener, 2005), happiness (Veenhoven, 2004), and sense of coherence (Antonovsky, 1993). Our datasets contained a question regarding the satisfaction with current life: "To what extent are you satisfied with your current life?" which was taken from the Satisfaction With Life Scale (Diener et al., 1985) Responses were categorized as 'satisfied or very satisfied' or 'not very or fairly satisfied'. The model variables were measured with identical questions and response categories in both the PPCD and POLS samples.

\section{RESULTS}

\section{Relationship between work and life satisfaction}

Firstly, we looked at the association of both paid and voluntary work with life satisfaction ratings for three populations: people with a chronic illness and a physical disability (from now on named 'people with physical disabilities'), people with a chronic illness without physical disability, and the general population (Table 2).

\section{[TABLE 2.]}

Table 2 shows that the percentage of satisfied people among people with physical disabilities is lower compared to the chronically ill without physical disabilities, and the general population. This finding is in line with the literature. More surprising is the difference in percentages of satisfied people between people with physical disabilities who work, paid or voluntary, and non-workers. The life satisfaction gap between people with disabilities with and without (paid or involuntary) work is 17 per cent points. When comparing the subgroup of people with and without paid work, the difference of 15 points is 
Campen, C. van, Cardol, M. When work and satisfaction with life do not go hand in hand: health barriers and personal resources in the participation of people with chronic physical disabilities.

Social Science \& Medicine: 2009, 69(1), 56-60

larger than the difference between employed and non-employed people with a chronic illness ( 3 points) and the non-disabled general population (4 points for paid work). People with chronic illness without disabilities resemble the general population to a larger extent. These results indicate that the relationship between work and life satisfaction among people with physical disabilities is different in two respects. Their life satisfaction ratings are lower, and the gap in life satisfaction between the workers and non-workers is larger.

\section{Distribution of work and life satisfaction}

In order to gain insight into these differences, we looked at the survey data from the perspective of 'satisfied participation' (see Introduction). Combining data on work participation and satisfaction with life, we categorized people into four groups: satisfied people with work, dissatisfied people with work, satisfied people without work and dissatisfied people without work. Table 3 shows the distribution of the four groups in three populations: people with physical disabilities, people with a chronic illness without physical disabilities, and the general population.

\section{[TABLE 3.]}

The first significant finding is the small percentage of satisfied people with work among people with a physical disability (16\%) in comparison to satisfied people with work among people with a chronic illness without physical disabilities (46\%) and in the general population $(50 \%)$.

A second finding is the large group of satisfied people without work. Among people with physical disabilities this group has the largest share (44\%). Its share is bigger than among people with a chronic illness without physical disabilities (38\%). Since voluntary work was not measured in the general population, we can only present the $39 \%$ of satisfied people with work as a, possibly overestimated, indication of the real percentage.

Thirdly, about one third of the group of people with physical disabilities belongs to the group 'dissatisfied people without work', which is a larger share than in the population of persons with a chronic illness without disabilities $(9 \%)$ and the general population (indicative percentage of 6\%). This is what we expected since people with physical disabilities have fewer opportunities to find work (cf. Office for Disability Studies, 2004). We checked if the distribution of the four groups among people with physical disabilities was very different for people aged 15-64 years and people of 65 years and over and for women and men. The group people aged 15-64 years have a share of $22 \%$ in the group satisfied people having work, mainly because the participation in work is higher for this group in comparison of the people of 65 years and over. Among people of 65 years and over the share of satisfied people without work was high (51\%). Among men, the group of satisfied people having work was larger (22\%) than among women $(13 \%)$.

The results of Table 3 provide an insight into the reasons why the relationship between life satisfaction and work in the population of people with physical disabilities is different in two respects: firstly, there are not so many workers who are satisfied with their life and, secondly, a large number of satisfied people do not work. In the next step we analysed the determining factors behind this exceptional distribution of work and life satisfaction among people with chronic physical disabilities.

\section{Determinants of work and life satisfaction}

We assume that satisfaction with life and participation in work are determined by a balance of barriers and resources. The following determinants were entered in the empirical model: age, sex, type and severity of the disability, co-morbidity, household composition, education, and net household income. The distribution of the four groups is the target variable of the model. We tested the model on the dataset of the sample of people with physical disabilities. We used stepwise discriminant analysis of the statistical software program SPSS to find the factors that make the difference between these groups. Given a set of independent variables, 
Campen, C. van, Cardol, M. When work and satisfaction with life do not go hand in hand: health/ barriers and personal resources in the participation of people with chronic physical disabilities.

Social Science \& Medicine: 2009, 69(1), 56-60

discriminant analysis attempts to find linear combinations of those variables that best separate the groups of cases. These combinations are called discriminant functions. In other words, what distinguishes a 'satisfied person with work' from a 'dissatisfied person without work' and the other two groups? The advantage of discriminant analysis is that four groups can be analysed together at the same time. We used a stepwise model to show the different effects of 'resource' and 'barrier' factors. In the first step we entered barrier factors such as health problems, in the second step demographic factors, and in step three, resource factors, including socio-economic ones. Table 4 shows the coefficients of the discriminating functions in the three steps of the model.

\section{[TABLE 4.]}

We started with a zero-model that predicts the distribution of people over the groups on the basis of chance, which is $25 \%$ (not in table) for each of the four groups. Model 1, including the barrier factors co-morbidity and disability, predicts $46.3 \%$ of the people correctly. Model 2 adds demographic characteristics and the number of correctly predicted people increases with 4.2 per cent points to $50.5 \%$. Finally, model 3 also includes the socio-economic factors, 'highest level of education' and 'net household income'. The total number of correctly predicted people increases further by 3.9 per cent points to $54.4 \%$. That means that the work and life satisfaction of more than half of the population of people with physical disabilities can be predicted on the basis of their level of disability, demographic and socio-economic characteristics.

In the third model the factors 'age' and 'education' load highest on the first function and the factors 'severity of total disability' and 'severity of motor disability' load highest on the second function. These results confirm the existence of 'barriers' and 'demographic and socio-economic resource factors' as distinct factors in the distribution of the four groups.

\section{DISCUSSION}

By analysing combinations of life satisfaction and participation in work as one outcome, we were able to take one step beyond the classical correlation studies of work and life satisfaction. Not only did we show statistically that the relationship between life satisfaction and work is different for people with physical disabilities, but also how the distribution of satisfying participation of people with chronic physical disabilities differs from the distribution in non-disabled populations. The share of satisfied people with work is lower, and satisfied people without work is higher, among people with physical disabilities.

The distributions are robust. This is because its main determinants are the severity of motor disability as the main barrier, and being younger and having a higher educational level as the most important demographic and resources factors that distinguish satisfied participants in work from the other groups.

However, there may be room for individual change, since the empirical model accounts for about half of the differences (54\%) in satisfying participation in work. The remaining variance of the model (46\%) could be explained by the process factors, covering a range of psychosocial variables such as attitudes, values (Ville \& Winance, 2006), competences, coping skills ([Lyubomirsky, 2008] and [Martz and Livneh, 2007]), and environmental factors, including access to the labour market, having social networks and private and public transport, affording participation and career opportunities (delle Fave \& Massimini, 2005).

The results of this study have political relevance. Many western societies stress the importance of work for the well-being of persons with physical disabilities. This study confirms the relationship between life satisfaction and work, but also shows that work cannot be the only factor of life satisfaction. In fact this study reveals a large group of satisfied yet non-working people with physical disabilities. A signal for policy makers from this study is to consider work, paid as well as voluntary, as not the only means to improve well-being. 
Campen, C. van, Cardol, M. When work and satisfaction with life do not go hand in hand: health/ barriers and personal resources in the participation of people with chronic physical disabilities. Social Science \& Medicine: 2009, 69(1), 56-60

Four out of ten people with a physical disability are satisfied without work. Getting everyone with chronic physical disabilities to work is simply unrealistic.

The results of this study can be used or implemented in social and health policy. Firstly, the study shows that there is a vast group of people with chronic physical disabilities who are satisfied with their life whilst they do not have a paid or voluntary job. This suggests to policy makers that getting a job does not, in a quite a number of cases, improve the wellbeing of the chronically ill and the disabled. Perhaps satisfied people without work cannot get satisfying work due, for instance, to severe disability, and/or other facets of their lives which may make them satisfied.

People with physical disabilities should have the same, equal, opportunities as other citizens without disabilities. This is a great policy objective that we subscribe too. However, having a severe motor disability can simply present considerable problems when trying to find a decent and rewarding job. It can even cause so much trouble that a person may choose not to work and seek instead other ways of realizing participation in society.

\section{REFERENCES}

Antonovsky, $1993 \mathrm{~A}$. Antonovsky, The structure and properties of the sense of coherence scale, Social Science \& Medicine 36 (1993), pp. 725-733. A

Argyle, 1989 M. Argyle, The psychology of happiness, Routledge, London (1989).

Bent et al., 2001 N. Bent, A. Jones, I. Molloy, M.A. Chamberlain and A. Tennant, Factors determining participation in young adults with a physical disability: a pilot study, Clinical Rehabilitation 15 (5) (2001), pp. 552-561.

van Campen and Cardol, 2007 C. van Campen and M. Cardol, Tevreden meedoen, Tijdschrift voor Gezondheidswetenschappen (TSG) 85 (7) (2007), pp. 375-376.

van Campen and ledema, 2007 C. van Campen and J. ledema, Are persons with physical disabilities who participate in society healthier and happier? Structural equation modelling of objective participation and subjective well-being, Quality of Life Research 16 (4) (2007), pp. 635-645.

Deci and Ryan, 2008 E.L. Deci and R.M. Ryan, Hedonia, eudaimonia, and well-being: an introduction, Journal of Happiness Studies 9 (2008), pp. 1-11.

Diener et al., 1985 E. Diener, R.A. Emmons, R.J. Larsen and S. Griffin, The satisfaction with life scale, Journal of Personality Assessment 49 (1) (1985), pp. 71-75.

Diener and Suh, $1997 \mathrm{E}$. Diener and E. Suh, Measuring quality of life: economical, social en subjective indicators, Social Indicators Research 40 (1-2) (1997), pp. 189-216.

Dijkers, 1999 M.P. Dijkers, Correlates of life satisfaction among persons with spinal cord injury, Archives of Physical Medicine and Rehabilitation 80 (8) (1999), pp. 867-876.

Edwards and Imrie, 2008 C. Edwards and R. Imrie, Disability and the implications of the wellbeing agenda: some reflections from the United Kingdom, Journal of Social Policy 37 (3) (2008), pp. 337-355.

delle Fave and Massimini, 2005 A. delle Fave and F. Massimini, The relevance of subjective well-being to social policies: optimal experience and tailored intervention. In: F.A. Huppert, N. Baylis and B. Keverne, Editors, The science of well-being, OUP, Oxford (2005), pp. 379-402.

Frey and Stutzer, 2002 B. Frey and A. Stutzer, Happiness and economics: How the economy and institutions affect human well-being, Princeton University Press (2002).

Heijmans et al., 2005 M.J.W.M. Heijmans, P. Spreeuwenberg and P.M. Rijken, Patiëntenpanel Chronisch zieken; Kerngegevens maatschappelijke situatie, NIVEL, Utrecht (2005).

van Lindert et al., $2006 \mathrm{H}$. van Lindert, M. Lambooij and G.P. Westert, Gezondheidstoestand naar arbeidsstatus; een vergelijking in de tijd (1987-2001), Tijdschrift voor Gezondheidswetenschappen (TSG) 84 (6) (2006), pp. 324-329.

Lyubomirsky, 2008 S. Lyubomirsky, The how of happiness, Penguin, New York (2008). Lyubomirsky et al., 2005 S. Lyubomirsky, L.A. King and E. Diener, The benefits of frequent positive affect: does happiness lead to success?, Psychological Bulletin 131 (2005), pp. 803-855. 
Campen, C. van, Cardol, M. When work and satisfaction with life do not go hand in hand: health/ barriers and personal resources in the participation of people with chronic physical disabilities.

Social Science \& Medicine: 2009, 69(1), 56-60

Manns and Chad, 1999 P.J. Manns and K.E. Chad, Determining the relation between quality of life, handicap, fitness, and physical activity for persons with spinal cord injury, Archives of Physical Medicine and Rehabilitation 80 (12) (1999), pp. 1566-1571.

Martz and Livneh, $2007 \mathrm{E}$. Martz and H. Livneh, Coping with spinal cord injuries: wholeness is a state of mind. In: E. Martz and H. Livneh, Editors, Coping with chronic illness and disability. Theoretical, empirical and clinical aspects, Springer, New York (2007).

OECD, 1981 OECD, OECD long-term disability questionnaire, Organisation for Economic Co-operation and Development, Paris (1981).

Office for Disability Issues, 2004 Office for Disability Issues, Advancing the inclusion of persons with disabilities, Government of Canada (2004) Consulted at http://www.hrsdc.gc.ca/en/hip/odi/documents/advancinglnclusion04/index.shtml.

Oswald and Powdthavee, 2006 Oswald, A. J., \& Powdthavee, N. Does happiness adapt? A longitudinal study of disability with implications for economists and judges. Bonn: IZA discussion paper Discussion Paper No. 2208, July 2006.

Post et al., 1998 M.W. Post, L.P. de Witte, F.W. van Asbeck, A.J. van Dijk and A.J.P. Schrijvers, Predictors of health status and life satisfaction in spinal cord injury, Archives of Physical Medicine and Rehabilitation 79 (4) (1998), pp. 395-401.

Tagalakis et al., $1988 \mathrm{~V}$. Tagalakis, R. Amsel and C.S. Fichten, Job interview strategies for people with a visible disability, Journal of Applied Social Psychology 18 (6) (1988), pp. 520-532.

Veenhoven, 2004 R. Veenhoven, Happiness as an aim in public policy: the greatest happiness principle. In: P.A. Linley and S. Joseph, Editors, Positive psychology in practice, Wiley, New York (2004), pp. 658-678.

Ville and Ravaud, 1998 I. Ville and J.F. Ravaud, Work values: a comparison of non-disabled persons with persons with paraplegia, Disability and Rehabilitation 20 (4) (1998), pp. 127137.

Ville and Ravaud, 2001 I. Ville and J.F. Ravaud, Subjective wellbeing and severe motor impairments: the Tetrafigap Survey on the long-term outcome of tetraplegic spinal cord injured persons, Social Science \& Medicine 52 (2001), pp. 369-384.

Ville and Winance, $2006 \mathrm{I}$. Ville and M. Winance, To work or not to work? The occupation trajectories of wheelchair users: a narrative approach, Disability and Rehabilitation 28 (7) (2006), pp. 423-436. 
Campen, C. van, Cardol, M. When work and satisfaction with life do not go hand in hand: health barriers and personal resources in the participation of people with chronic physical disabilities. Social Science \& Medicine: 2009, 69(1), 56-60

\section{TABLES}

Table 1

Sample characteristics (percentages).

\begin{tabular}{|c|c|c|c|}
\hline & $\begin{array}{l}\text { Persons with } \\
\text { chronic illness and } \\
\text { physical disabilities }\end{array}$ & $\begin{array}{l}\text { Persons with chronic } \\
\text { illness without } \\
\text { physical disabilities }\end{array}$ & $\begin{array}{c}\text { General } \\
\text { population }\end{array}$ \\
\hline \multicolumn{4}{|l|}{ Gender } \\
\hline Male & 35 & 46 & 48 \\
\hline Female & 65 & 54 & 52 \\
\hline \multicolumn{4}{|l|}{ Age } \\
\hline 15-34 Years & 3 & 12 & 33 \\
\hline 35-64 Years & 43 & 60 & 51 \\
\hline 65 Years and older & 54 & 28 & 16 \\
\hline \multicolumn{4}{|c|}{ Household composition } \\
\hline Single & 21 & 11 & 15 \\
\hline Cohabiting/unknown & 79 & 89 & 85 \\
\hline \multicolumn{4}{|l|}{ Socio-economic status } \\
\hline $\begin{array}{l}\text { Low level of } \\
\text { education }^{\mathrm{a}}\end{array}$ & 23 & 11 & \\
\hline $\begin{array}{l}\text { Low net household } \\
\text { income }\end{array}$ & 27 & 13 & \\
\hline \multicolumn{4}{|l|}{ Participation } \\
\hline Paid work & 9 & 37 & 45 \\
\hline Voluntary work & 14 & 26 & \\
\hline$n$ & 603 & 1199 & 6128 \\
\hline
\end{tabular}

Source: PPCD 2002-2004, POLS 2002.

${ }^{\mathrm{a}}$ Low level of education $=$ no education or primary school.

${ }^{\mathrm{b}}$ Low income $=$ net household income is less than 1500 euro per month. 
Campen, C. van, Cardol, M. When work and satisfaction with life do not go hand in hand: health barriers and personal resources in the participation of people with chronic physical disabilities.

Social Science \& Medicine: 2009, 69(1), 56-60

Table 2

Satisfaction with life among participants in work and non-participants in three populations (percentages).

\begin{tabular}{|c|c|c|c|}
\hline & $\begin{array}{l}\text { People with } \\
\text { chronic illness and } \\
\text { physical disabilities }\end{array}$ & $\begin{array}{l}\text { People with } \\
\text { chronic illness } \\
\text { without physical } \\
\text { disabilities }\end{array}$ & $\begin{array}{l}\text { General } \\
\text { population }\end{array}$ \\
\hline \multicolumn{4}{|c|}{ Paid work } \\
\hline Yes & 73 & 85 & 92 \\
\hline No & 58 & 82 & 88 \\
\hline \multicolumn{4}{|c|}{ Voluntary work } \\
\hline Yes & 74 & 88 & \\
\hline No & 57 & 82 & \\
\hline \multicolumn{4}{|c|}{ Paid or voluntary work } \\
\hline Yes & 73 & 86 & \\
\hline No & 56 & 80 & \\
\hline Total & 59 & 83 & 91 \\
\hline$n$ & 600 & 1191 & 6027 \\
\hline
\end{tabular}

Source: PPCD 2002-2004, POLS 2002.

${ }^{a}$ Only paid work regarded, not voluntary work. 
Campen, C. van, Cardol, M. When work and satisfaction with life do not go hand in hand: healthe barriers and personal resources in the participation of people with chronic physical disabilities.

Social Science \& Medicine: 2009, 69(1), 56-60

Table 3

Distribution of four groups of (dis)satisfied people with(out) work in three populations (percentages).

\begin{tabular}{|l|l|l|l|}
\hline & $\begin{array}{l}\text { People with chronic } \\
\text { illness and physical } \\
\text { disabilities }\end{array}$ & $\begin{array}{c}\text { People with chronic } \\
\text { illness without physical } \\
\text { disabilities }\end{array}$ & $\begin{array}{c}\text { General } \\
\text { population }\end{array}$ \\
\hline $\begin{array}{c}\text { Satisfied people } \\
\text { with work }\end{array}$ & 16 & 46 & 50 \\
\hline $\begin{array}{c}\text { Dissatisfied } \\
\text { people with work }\end{array}$ & 6 & 8 & 5 \\
\hline $\begin{array}{c}\text { Satisfied people } \\
\text { without work }\end{array}$ & 44 & 38 & 39 \\
\hline $\begin{array}{c}\text { Dissatisfied } \\
\text { people without } \\
\text { work }\end{array}$ & 35 & 9 & 6 \\
\hline & 100 & 100 & 100 \\
\hline Total & 600 & 1191 & 6027 \\
\hline$n$ & & & \\
\hline
\end{tabular}

Source: PPCD 2002-2004, POLS 2002.

${ }^{a}$ Only paid work regarded, not voluntary work. 
Campen, C. van, Cardol, M. When work and satisfaction with life do not go hand in hand: health barriers and personal resources in the participation of people with chronic physical disabilities.

Social Science \& Medicine: 2009, 69(1), 56-60

Table 4

Discriminating functions between four groups of (dis)satisfied people with(out) work (coefficients ${ }^{\mathrm{a}}$ ).

\begin{tabular}{|c|c|c|c|c|c|}
\hline & \multirow{2}{*}{$\begin{array}{c}\text { Model } 1 \\
\text { Function } 1\end{array}$} & \multicolumn{2}{|l|}{ Model 2} & \multicolumn{2}{|l|}{ Model 3} \\
\hline & & Function 1 & Function 2 & Function 1 & Function 2 \\
\hline \multicolumn{6}{|l|}{ Disabilities } \\
\hline Motor disabilities & 0.866 & 0.666 & 0.425 & 0.450 & 0.598 \\
\hline Severity of disability & 0.711 & 0.546 & 0.349 & 0.371 & 0.488 \\
\hline Hearing disabilities & 0.091 & -0.035 & 0.403 & -0.112 & 0.244 \\
\hline Visual disabilities & 0.125 & 0.099 & 0.033 & 0.088 & 0.058 \\
\hline Co-morbidity & 0.284 & 0.276 & -0.080 & 0.257 & 0.068 \\
\hline \multicolumn{6}{|l|}{ Demographics } \\
\hline Gender & & 0.286 & -0.161 & 0.282 & 0.021 \\
\hline Age & & 0.647 & -0.495 & 0.641 & -0.021 \\
\hline Household composition & & 0.163 & 0.186 & 0.086 & 0.206 \\
\hline \multicolumn{6}{|l|}{ SES } \\
\hline Highest level of education & & & & -0.609 & 0.453 \\
\hline Net household income & & & & -0.255 & -0.166 \\
\hline$\%$ Predicted correctly & 46.3 & 50.5 & & 54.4 & \\
\hline
\end{tabular}

Source: PPCD 2002-2004.

${ }^{a}$ Coefficients are correlations between variables and standardized discriminant functions. The higher the correlation coefficient, the better the variable distinguishes between the four groups. Only significant $(p<.05)$ functions are reported in the table. 